\title{
Isolation of Cellulose-Degrading Bacteria and Determination of Their Cellulolytic Potential
}

\author{
Pratima Gupta, ${ }^{1}$ Kalpana Samant, ${ }^{2}$ and Avinash Sahu ${ }^{2}$ \\ ${ }^{1}$ Department of Biotechnology, National Institute of Technology, Raipur 492 010, India \\ ${ }^{2}$ Indian Institute of Technology Delhi, New Delhi 110016, India \\ Correspondence should be addressed to Pratima Gupta, prati_biotech@yahoo.co.in
}

Received 29 July 2011; Accepted 11 October 2011

Academic Editor: Todd R. Callaway

Copyright ( 2012 Pratima Gupta et al. This is an open access article distributed under the Creative Commons Attribution License, which permits unrestricted use, distribution, and reproduction in any medium, provided the original work is properly cited.

\begin{abstract}
Eight isolates of cellulose-degrading bacteria (CDB) were isolated from four different invertebrates (termite, snail, caterpillar, and bookworm) by enriching the basal culture medium with filter paper as substrate for cellulose degradation. To indicate the cellulase activity of the organisms, diameter of clear zone around the colony and hydrolytic value on cellulose Congo Red agar media were measured. CDB 8 and CDB 10 exhibited the maximum zone of clearance around the colony with diameter of 45 and $50 \mathrm{~mm}$ and with the hydrolytic value of 9 and 9.8, respectively. The enzyme assays for two enzymes, filter paper cellulase (FPC), and cellulase (endoglucanase), were examined by methods recommended by the International Union of Pure and Applied Chemistry (IUPAC). The extracellular cellulase activities ranged from 0.012 to $0.196 \mathrm{IU} / \mathrm{mL}$ for FPC and 0.162 to $0.400 \mathrm{IU} / \mathrm{mL}$ for endoglucanase assay. All the cultures were also further tested for their capacity to degrade filter paper by gravimetric method. The maximum filter paper degradation percentage was estimated to be 65.7 for CDB 8. Selected bacterial isolates CDB 2, 7, 8, and 10 were co-cultured with Saccharomyces cerevisiae for simultaneous saccharification and fermentation. Ethanol production was positively tested after five days of incubation with acidified potassium dichromate.
\end{abstract}

\section{Introduction}

Cellulose is a linear polysaccharide of glucose residues with $\beta$-1, 4-glycosidic linkages. Abundant availability of cellulose makes it an attractive raw material for producing many industrially important commodity products. Sadly, much of the cellulosic waste is often disposed of by biomass burning, which is not restricted to developing countries alone, but is considered a global phenomenon. With the help of cellulolytic system, cellulose can be converted to glucose which is a multiutility product, in a much cheaper and biologically favourable process.

Cellulolysis is basically the biological process controlled and processed by the enzymes of cellulase system. Cellulase enzyme system comprises three classes of soluble extracellular enzymes: $1,4-\beta$-endoglucanase, $1,4-\beta$-exoglucanase, and $\beta$-glucosidase ( $\beta$-D-glucoside glucohydrolase or cellobiase). Endoglucanase is responsible for random cleavage of $\beta-1$, 4 -glycosidic bonds along a cellulose chain. Exoglucanase is necessary for cleavage of the nonreducing end of a cellulose chain and splitting of the elementary fibrils from the crystalline cellulose, and $\beta$-1, 4-glucosidase hydrolyses cellobiose and water-soluble cellodextrin to glucose $[1,2]$. Only the synergy of the above three enzymes makes the complete cellulose hydrolysis to glucose [3-5] or a thorough mineralization to $\mathrm{H}_{2} \mathrm{O}$ and $\mathrm{CO}_{2}$ possible.

Source for cellulase system extraction is best suitable from microbial system found in the gut of organisms thriving on cellulosic biomasses as their major feed. Insects like termites (Isopteran), bookworm (Lepidoptera), and so forth, are found to have syntrophic symbiotic microflora in their guts responsible for cellulosic feed digestion $[6,7]$. Many microorganisms have been reported with cellulosic activities including many bacterial and fungal strains both aerobic and anaerobic. Chaetomium, Fusarium Myrothecium, Trichoderma. Penicillium, Aspergillus, and so forth, are some of the reported fungal species responsible for cellulosic biomass hydrolysation. Cellulolytic bacterial species include Trichonympha, Clostridium, Actinomycetes, Bacteroides succinogenes, Butyrivibrio fibrisolvens, Ruminococcus albus, and Methanobrevibacter ruminantium $[8,9]$. 
Cellulase due to its massive applicability has been used in various industrial processes such as biofuels like bioethanol [10, 11], triphasic biomethanation [12]; agricultural and plant waste management $[13,14]$; chiral separation and ligand binding studies [15].

The present work concentrates on the isolation of cellulose-degrading bacteria from invertebrates such as termites, snails, caterpillars, and bookworms and assessment of their cellulolytic activity. The coculturing of cellulose-degrading bacteria and yeast was also carried out for simultaneous saccharification and fermentation of cellulose into ethanol.

\section{Materials and Methods}

2.1. Sample Collection. Cellulose feeding organisms like termite, caterpillar, bookworm, and snail were collected for isolation of cellulose-degrading bacteria from woody habitats. Guts of the collected organism were separately crushed in $0.9 \%$ saline solution under sterile condition.

2.2. Isolation and Screening of Cellulose-Degrading Bacteria. The macerated gut of the collected organisms was inoculated in a basal salt media $\left(\mathrm{NaNO}_{3} 2.5 \mathrm{~g} ; \mathrm{KH}_{2} \mathrm{PO}_{4} 2 \mathrm{~g} ; \mathrm{MgSO}_{4}\right.$ $0.2 \mathrm{~g} ; \mathrm{NaCl} 0.2 \mathrm{~g} ; \mathrm{CaCl}_{2} \cdot 6 \mathrm{H}_{2} \mathrm{O} 0.1 \mathrm{~g}$ in a liter) containing filter paper (Whatman filter paper no. 1 of area $70.541 \mathrm{~cm}^{2}$ ) for the isolation of cellulolytic bacteria. These cultures were incubated for 7 days in a shaker incubator at $37^{\circ} \mathrm{C}$ at $100 \mathrm{rpm}$. Bacterial colonies capable of utilizing cellulose as sole source of carbon were isolated on cellulose agar media composed of $\mathrm{KH}_{2} \mathrm{PO}_{4} 0.5 \mathrm{~g} \mathrm{MgSO}_{4} 0.25 \mathrm{~g}$ cellulose $2.0 \mathrm{~g}$ agar $15 \mathrm{~g}$ gelatin $2 \mathrm{~g}$ and distilled water $\mathrm{IL}$ and at $\mathrm{pH}$ 6.8-7.2.

Confirmation of cellulose-degrading ability of bacterial isolates was performed by streaking on the cellulose CongoRed agar media with the following composition: $\mathrm{KH}_{2} \mathrm{PO}_{4}$ $0.5 \mathrm{~g}, \mathrm{MgSO}_{4} 0.25 \mathrm{~g}$, cellulose $2 \mathrm{~g}$, agar $15 \mathrm{~g}$, Congo-Red $0.2 \mathrm{~g}$, and gelatin $2 \mathrm{~g}$; distilled water $1 \mathrm{~L}$ and at $\mathrm{pH} 6.8-$ 7.2. The use of Congo-Red as an indicator for cellulose degradation in an agar medium provides the basis for a rapid and sensitive screening test for cellulolytic bacteria. Colonies showing discoloration of Congo-Red were taken as positive cellulose-degrading bacterial colonies [13], and only these were taken for further study. Cellulose-degrading potential of the positive isolates was also qualitatively estimated by calculating hydrolysis capacity (HC), that is, the ratio of diameter of clearing zone and colony [16].

2.3. Enzyme Production. The selected CDB isolates were cultured at $37^{\circ} \mathrm{C}$ at $150 \mathrm{rpm}$ in an enzyme production media composed of $\mathrm{KH}_{2} \mathrm{PO}_{4} 0.5 \mathrm{~g}, \mathrm{MgSO}_{4} 0.25 \mathrm{~g}$, and gelatin $2 \mathrm{~g}$, distilled water $1 \mathrm{~L}$ and containing Whatman filter paper No.1 $(1 \times 6 \mathrm{~cm}$ strip, $0.05 \mathrm{~g}$ per $20 \mathrm{~mL})$ and at $\mathrm{pH} 6.8-7.2$. Broth culture after three days of incubation period was subjected to centrifugation at $5000 \mathrm{rpm}$ for $15 \mathrm{~min}$ at $4^{\circ} \mathrm{C}$. Supernatant was collected and stored as crude enzyme preparation at $4^{\circ} \mathrm{C}$ for further enzyme assays. Pellet recovered after centrifugation of broth culture was subjected to gravimetric analysis in order to determine the residual cellulose of filter paper [17].

2.4. Enzyme Assay. Total cellulose activity was determined by measuring the amount of reducing sugar formed from filter paper. Endoglucanase ( $\beta 1-4$ endoglucanase-EC 3.2.1.4) activity was assayed by measuring the amount of reducing sugar from amorphous cellulose. The enzyme activity was determined according to the methods recommended by the International Union of Pure and Applied Chemistry (IUPAC) commission on biotechnology [18]. Endoglucanase activity was determined by incubating $0.5 \mathrm{~mL}$ of supernatant with $0.5 \mathrm{~mL}$ of $2 \%$ amorphous cellulose in $0.05 \mathrm{~m}$ sodium citrate buffer $(\mathrm{pH} 4.8)$ at 50 for $30 \mathrm{~min}$. FPC activity was determined by incubating $0.5 \mathrm{~mL}$ of supernatant with $1.0 \mathrm{~mL}$ of $0.05 \mathrm{M}$ sodium citrate buffer $(\mathrm{pH} 4.8)$ containing Whatman no.1 filter paper strip-1.0 $\times 6.0 \mathrm{~cm}(=50 \mathrm{mg})$. After incubation for an hour at $50^{\circ} \mathrm{C}$, the reaction was terminated by adding $3 \mathrm{~mL}$ of 3,5 -dinitrosalicylic acid (DNS) reagent to $1 \mathrm{~mL}$ of reaction mixture. In these tests, reducing sugars were estimated spectrophotometrically with 3, 5-dinitrosalicylic acid [19] using glucose as standards. The enzymatic activity of total FPCase and endoglucanase were defined in international units (IU). One unit of enzymatic activity is defined as the amount of enzyme that releases $1 \mu \mathrm{mol}$ reducing sugars (measured as glucose) per $\mathrm{mL}$ per minute.

2.5. Bioethanol Production. A total of four isolates CDB $2,7,8$, and 10 were grown in mixed culture using basal salt medium in two different sets, one containing filter paper and the other containing cellulose powder as substrate for production of cellulolytic enzyme and to initiate saccharification process. Culture was incubated at $37^{\circ} \mathrm{C}$ with mixing at $100 \mathrm{rpm}$ for 3 days. After completion of three days of incubation, the above culture broth was conditioned for coculturing of Saccharomyces cerevisae by addition of filter-sterilized salt solution $\left(\mathrm{KH}_{2} \mathrm{PO}_{4} 0.4 \mathrm{~g}, \mathrm{MgSO}_{4} 0.02 \mathrm{~g}\right.$, $\mathrm{CaCO}_{3} 0.05 \mathrm{~g}$, and $\mathrm{NaCl} 0.01 \mathrm{~g}$ to $1 \mathrm{~L}$ culture broth). The simultaneous saccharification and fermentation was carried out at $27^{\circ} \mathrm{C}$ for 5 days in stationary condition. At the end of incubation, the culture broth was qualitatively tested for alcohol production using the $\mathrm{K} 2 \mathrm{Cr} 2 \mathrm{O} 7$ reagent test [20].

\section{Result and Discussion}

3.1. Isolation and Screening of Cellulose-Degrading Bacteria. Cellulose degrading bacteria were enriched and isolated by inoculating filter paper in liquid medium with macerated guts from termite, bookworm, snail, and caterpillar separately. All bacterial culture showed growth as the medium turned cloudy and the filter paper became macerated. Cellulolytic bacteria were also isolated from gut of insects by R. J. Dillon and V. M. Dillon. [6], Wenzel et al. [21], Delalibera et al. [22], and Ramrn et al. [23]. A total of eight bacterial isolates found to be positive on screening media (cellulose Congo-Red agar) producing clear zone (as shown in Figure 1) during aerobic incubation were as follows: CDB 
TABle 1: Maximum clearing zone and hydrolytic capacity (HC) value of CDB on cellulose Congo red agar media. This table shows the assessment of bacterial isolates from the different source organism for cellulose decomposition via measurement of clear zone around the colony and calculation of hydrolytic value in cellulose Congo Red media. Maximum clearing zone of $50 \mathrm{~mm}$ and $\mathrm{HC}$ value of 9.8 were estimated for CDB 10 .

\begin{tabular}{lcccc}
\hline Source organism & Isolate number & Maximum clearing zone $(\mathrm{mm})$ & Average hc value & Maximum HC value \\
\hline \multirow{4}{*}{ Termite } & CDB1 & 30 & 5.49 & 6.77 \\
& CDB2 & 42 & 4.29 & 8.4 \\
& CDB8 & 45 & 5.36 & 9 \\
\hline \multirow{2}{*}{ Snail } & CDB9 & 28 & 4.32 & 4.39 \\
& CDB6 & 40 & 3.45 & 5.45 \\
\hline Bookworm & CDB10 & 50 & 5.96 & 9.8 \\
\hline Caterpillar & CDB3 & 30 & 3.51 & 4.3 \\
\hline
\end{tabular}

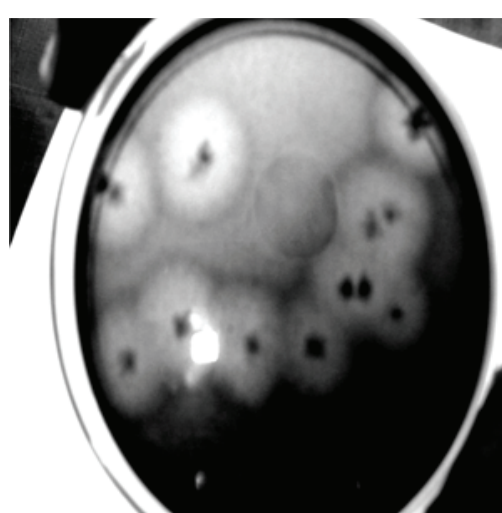

FIgure 1: Zone of clearance on cellulose Congo Red agar plates for isolate CDB 10 after $48 \mathrm{hrs}$ of incubation. The formation of clearing zone around the colonies confirms the secretion of extracellular cellulase.

$1,2,8$, and 9 from termite, CDB 6 and 10 from snail, CDB 3 from bookworm, and CDB 7 from caterpillar. The result showed that clearing zone and $\mathrm{HC}$ value ranged to bebetween 28.0 to $50.0 \mathrm{~mm}$ and 4.3 to 9.0 for all isolates (Table 1). The range of $\mathrm{HC}$ value obtained is similar to range reported by Lu et al. [24] whereas Hatami et al. [25] found the hydrolytic value between 1.38 to 2.33 and 0.15 to 1.37 of cellulolytic aerobic bacterial isolates from farming and forest soil, respectively.

3.2. Cellulolytic Potential of Bacterial Isolates. A total of eight positive isolates $(\mathrm{CDB} 1,2,3,6,7,8,9$, and 10) were selected for enzyme production and their respective cellulolytic activity was estimated. Enzyme assay for cellulase activity on filter paper was found to be highest for CDB 10 with $0.194 \mathrm{IU} / \mathrm{mL}$, while for endoglucanase assay maximum activity was determined to be $0.400 \mathrm{IU} / \mathrm{mL}$ by CDB 8 . The activities ranged from 0.012 to $0.196 \mathrm{IU} / \mathrm{mL}$ for FPCase and 0.1622 to $0.400 \mathrm{IU} / \mathrm{mL}$ for endoglucanase assay. The two isolates CDB8 and CDB10 exhibited the highest extracellular cellulase activities compared to other isolates as shown in activity assay performed for all isolates in Figure 2. Similar results were reported for Acinetobacter anitratus and

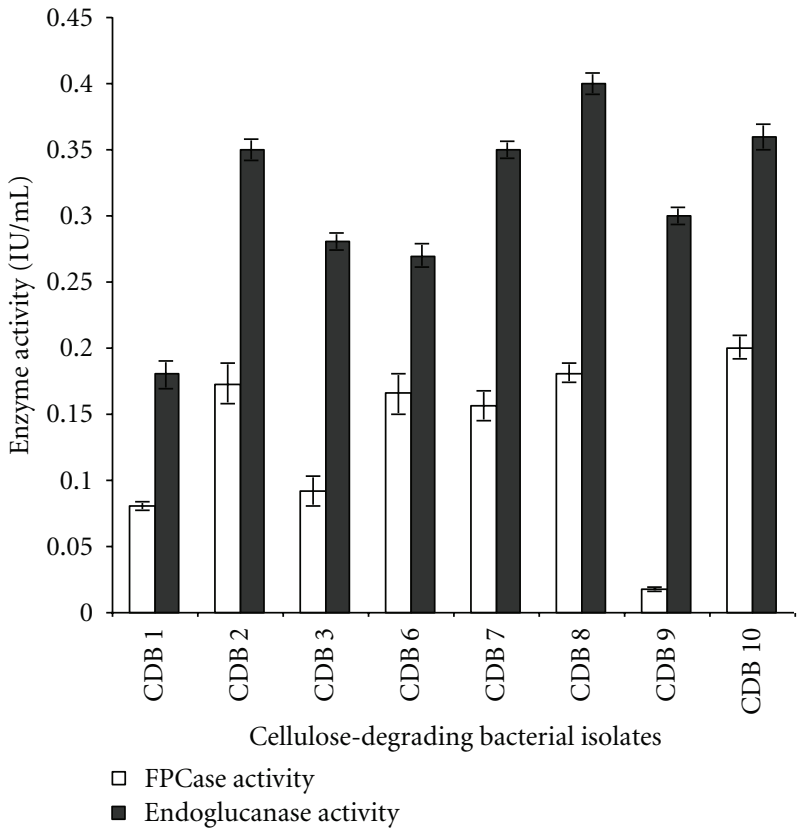

Figure 2: Extracellular cellulase activity of two enzymes (FPCase and endoglucanase) of all CDBs isolates. The activities ranged from 0.012 to $0.196 \mathrm{IU} / \mathrm{mL}$ for FPCase and 0.1622 to $0.400 \mathrm{IU} / \mathrm{mL}$ for endoglucanase assay. Values in figure are means of three replicates with standard deviation.

Branhamella sp. grown in a basic salt medium with glucose and CMC as sole carbon source separately. Ekperigin [10] quantitatively determined the cellulase degrading enzyme of $A$. anitratus and Branhamella sp. The maximum enzyme activities of $A$. anitratus culture supernatant were 0.48 and $0.24 \mathrm{U} / \mathrm{mL}$ for $\mathrm{CMC}$ and glucose, respectively. For Branhamella sp., the maximum enzyme activities of the culture supernatant were 2.56 and $0.34 \mathrm{U} / \mathrm{mL}$ for CMC and glucose, respectively. The filter paper degradation was observed separately in CDB 2, 3, 6, 7, 8, 9, and 10 as shown in Figure 3. Gravimetric analysis shows that maximum and minimum rates of filter paper degradation were $65.7 \%$ and $55 \%$, respectively, estimated at third day of incubation. An average of $57.64 \%$ degradation rate was computed. Figure 4 

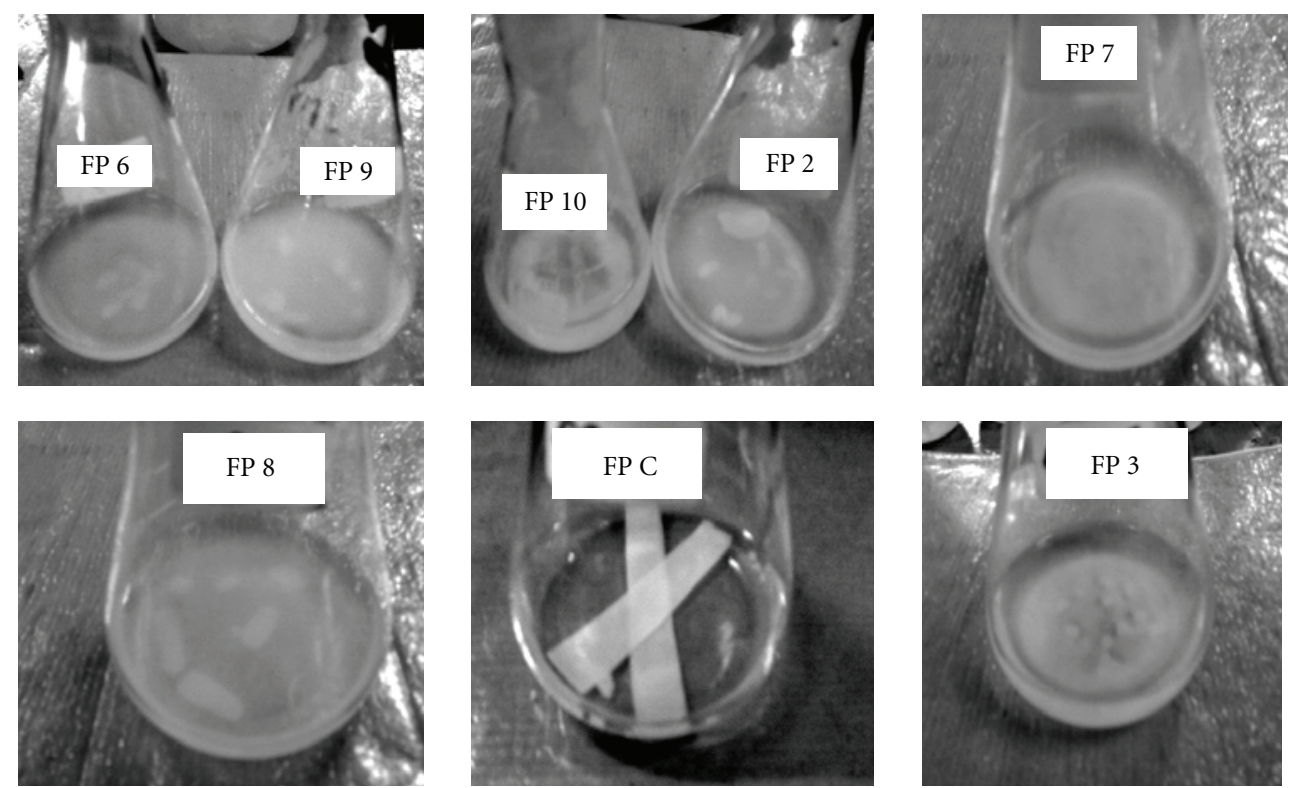

Figure 3: Filter paper degradation by isolates $\mathrm{CDB} 2,3,6,7,8,9$, and 10 cultured in basal salt medium supplemented with Whatman filter paper no. $1(1 \times 6 \mathrm{~cm}$ strip $\times 2,0.05 \mathrm{~g}$ per $20 \mathrm{~mL})$ at the end of $96 \mathrm{hrs}$ of incubation. Flask FP C is the control for this experimental set up and does not show any filter paper degradation.

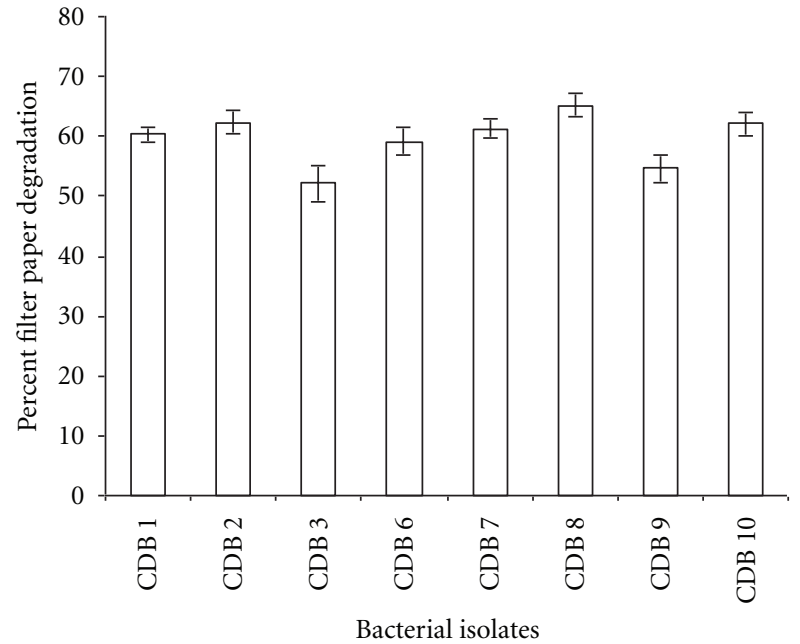

Figure 4: Percent filter paper degradation by various bacterial isolates obtained from termite, snail, bookworm, and caterpillar by gravimetric method. Maximum percentage of filter paper degradation was found to be $65.7 \%$ by CDB 8 . Values in figure are means of three replicates with standard deviation.

shows that $\mathrm{CDB} 8$ has highest filter paper degradation rate of $65.7 \%$. In a result documented by Lu et al. [13], the data for synergetic cellulose degradation detected in four groups of mixed cultures were only $23.5 \%, 26.3 \%, 19.4 \%$, and $24.5 \%$, respectively. Bichet-Hebe et al. [26] reported the rates of paper degradation ranged from 31 to $60 \%$ after 10 days for mixed bacterial populations by gravimetric procedure.
3.3. Bioethanol Production. The experiment setup for simultaneous saccharification and fermentation of mixed bacterial culture (CDB, 2, 7, 8, and 10) with Saccharomyces cerevisiae resulted in production of ethanol. This result expressed the high cellulolytic potential of these selected bacterial isolates for decomposition of cellulose and its fermentation for production of ethanol. Satheesh Kumar et al. [27] also used Whatman filter paper and cellulose powder as substrate in submerged fermentation for production of cellulolytic enzymes by Bacillus sp. FME (flour mill effluent). Coculturing of bacterial strains with yeast sp. and simultaneous saccharification and fermentation of ethanol were reported by several workers (Lenziou et al. [28] and Eklund and Zacchi [29]). Results indicated that significant synergistic cellulose degradation can be achieved in mixed culture system of cellulolytic bacteria and noncellulolytic yeast in which noncellulolytic yeast, Saccharomyces cerevisiae utilizes the reducing sugar derived from cellulose degradation and converts it to ethanol.

The bacterial isolates showed a potential to convert cellulose into reducing sugars which could be readily used in many applications like feed stock for production of valuable organic compounds; for example in the present study this has been demonstrated by simultaneous saccharification and fermentation of cellulose into ethanol.

\section{References}

[1] J. G. Shewale, "Glucosidase: its role in cellulase synthesis and hydrolysis of cellulose," International Journal of Biochemistry, vol. 14 , no. 6, pp. 435-443, 1982. 
[2] J. Woodward and A. Wiseman, "Fungal and other $\beta$-dglucosidases: their properties and applications," Enzyme and Microbial Technology, vol. 4, no. 2, pp. 73-79, 1983.

[3] D. D. Y. Ryu and M. Mandels, "Cellulases: biosynthesis and applications," Enzyme and Microbial Technology, vol. 2, no. 2, pp. 91-102, 1980.

[4] D. K. Samdhu and S. Bawa, "Improvement of cellulase activity in Trichoderma," Applied Biochemistry and Biotechnology, vol. 34-35, no. 1, pp. 175-192, 1992.

[5] T. M. Wood, "Synergism between enzyme components of Penicillium pinophilum cellulase in solubilizing hydrogen ordered cellulose," Journal of Biochemistry, vol. 260, pp. 37-43, 1989.

[6] R. J. Dillon and V. M. Dillon, "The gut bacteria of insects nonpathogenic interaction," Annual Review of Entomology, vol. 49, pp. 71-92, 2004.

[7] S. Saxena, J. Bahadur, and A. Varma, "Cellulose and hemicellulose degrading bacteria from termite gut and mould soils of India," The Indian Journal of Microbiology, vol. 33, pp. 55-60, 1993.

[8] M. A. Milala, A. Shugaba, A. Gidado, A. C. Ene, and J. A. Wafar, "Studies on the use of agricultural wastes for cellulase enzyme production by A. niger," Journal of Agriculture and Biological Science, vol. 1, pp. 325-328, 2005.

[9] W. H. Schwarz, "The cellulosome and cellulose degradation by anaerobic bacteria," Applied Microbiology and Biotechnology, vol. 56, no. 5-6, pp. 634-649, 2001.

[10] M. M. Ekperigin, "Preliminary studies of cellulase production by Acinetobacter anitratus and Branhamella sp," African Journal of Biotechnology, vol. 6, no. 1, pp. 28-33, 2007.

[11] P. Vaithanomsat, S. Chuichulcherm, and W. Apiwatanapiwat, "Bioethanol production from enzymatically saccharified sunflower stalks using steam explosion as pretreatment," Proceedings of World Academy of Science, Engineering and Technology, vol. 37, pp. 140-143, 2009.

[12] N. Chakraborty, G. M. Sarkar, and S. C. Lahiri, "Cellulose degrading capabilities of cellulolytic bacteria isolated from the intestinal fluids of the silver cricket," Environmentalist, vol. 20, no. 1, pp. 9-11, 2000.

[13] W. J. Lu, H. T. Wang, Y. F. Nie et al., "Effect of inoculating flower stalks and vegetable waste with ligno-cellulolytic microorganisms on the composting process," Journal of Environmental Science and Health, Part B, vol. 39, no. 5-6, pp. 871887, 2004

[14] A. Y. Mswaka and N. Magan, "Wood degradation, and cellulase and ligninase production, by Trametes and other wood-inhabiting basidiomycetes from indigenous forests of Zimbabwe," Mycological Research, vol. 102, no. 11, pp. 1399 1404, 1998.

[15] A. Nutt, V. Sild, G. Prtterson, and G. Johansson, "Progress curve as a means for functional classification of cellulases," Europian Journal of Biochemistry, vol. 258, p. 200, 1998.

[16] C. W. Hendricks, J. D. Doyle, and B. Hugley, "A new solid medium for enumerating cellulose-utilizing bacteria in soil," Applied and Environmental Microbiology, vol. 61, no. 5, pp. 2016-2019, 1995.

[17] P. Tailliez, H. Girard, J. Millet, and P. Beguin, "Enhanced cellulose fermentation by an asprogenous and ethanol tolerant mutant of Clostridium thermocellum," Applied Environmental Microbiology, vol. 55, pp. 207-211, 1989.

[18] T. K. Ghose, "Mesurnment of cellulase activity," Pure and Applied Chemistry, vol. 59, pp. 257-268, 1987.
[19] G. L. Miller, "Use of dinitrosalicylic acid reagent for determination of reducing sugar," Analytical Chemistry, vol. 31, no. 3, pp. 426-428, 1959.

[20] S. Poznanski, "The analysis of mixtures of ethyl alcohol, ethyl acetate, acetic acid and water," Journal of the American Chemical Society, vol. 50, no. 4, pp. 981-988, 1928.

[21] M. Wenzel, I. Schönig, M. Berchtold, P. Kämpfer, and H. König, "Aerobic and facultatively anaerobic cellulolytic bacteria from the gut of the termite Zootermopsis angusticollis," Journal of Applied Microbiology, vol. 92, no. 1, pp. 32-40, 2002.

[22] I. Delalibera Jr., J. Handelsman, and K. F. Raffa, "Contrasts in cellulolytic activities of gut microorganisms between the wood borer, Saperda vestita (Coleoptera: Cerambycidae), and the bark beetles, Ips pini and Dendroctonus frontalis (Coleoptera: Curculionidae)," Environmental Entomology, vol. 34, no. 3, pp. 541-547, 2005.

[23] M. Ramrn, A. R. Alimon, K. Sijam, and N. Abdullah, "Filter paper degradation by bacteria isolated from local termite gut," Research Journal of Microbiology, vol. 3, no. 8, pp. 565-568, 2008.

[24] W. J. Lu, H. T. Wang, S. J. Yang, Z. C. Wang, and Y. F. Nie, "Isolation and characterization of mesophilic cellulose-degrading bacteria from flower stalks-vegetable waste co-composting system," Journal of General and Applied Microbiology, vol. 51, no. 6, pp. 353-360, 2006.

[25] S. Hatami, H. A. Alikhsni, H. Besharati, N. salehrastin, M. Afrousheh, and Z. Y. Jahromi, "Investigation of aerobic cellulolytic bacteria in some of noeth forest and farming soils," The American-Eurasian Journal of Agricultural \& Environmental Sciences, vol. 5, pp. 713-716, 2008.

[26] I. Bichet-Hebe, A. M. Pourcher, L. Sutra, C. Comel, and G. Moguedet, "Detection of a whitening fluorescent agent as an indicator of white paper biodegradation: a new approach to study the kinetics of cellulose hydrolysis by mixed cultures," Journal of Microbiological Methods, vol. 37, no. 2, pp. 101-109, 1999.

[27] G. Satheesh Kumar, M. Subhosh Chandra, M. Sumanth, A. Vishnupriya, B. Rajasekhar Reddy, and Y. L. Choi, "Cellulolytic enzymes from submerged fermentation of different substrates by newly isolated Bacillus Spp. FME." Journal of Korean Society of Applied Biological Chemistry, vol. 52, pp. 1721, 2009.

[28] V. Lenziou, P. Christakopoulos, D. Kekos, and B. J. Macris, "Simultaneous saccharification and fermentation of sweet sorghum carbohydrates to ethanol in a fed-batch process," Biotechnology Letters, vol. 16, no. 9, pp. 983-988, 1994.

[29] R. Eklund and G. Zacchi, "Simultaneous saccharification and fermentation of steam-pretreated willow," Enzyme and Microbial Technology, vol. 17, no. 3, pp. 255-259, 1995. 

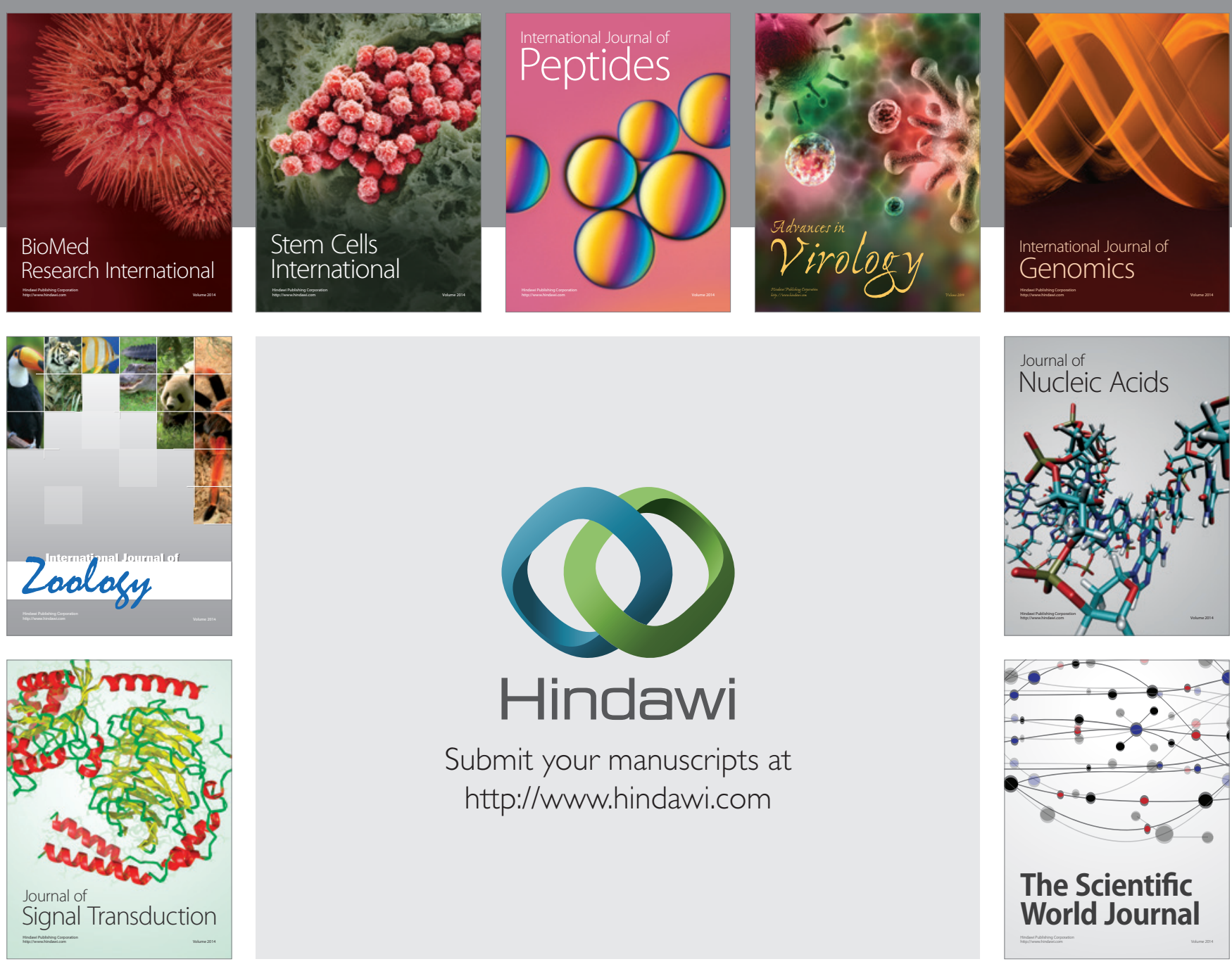

Submit your manuscripts at

http://www.hindawi.com
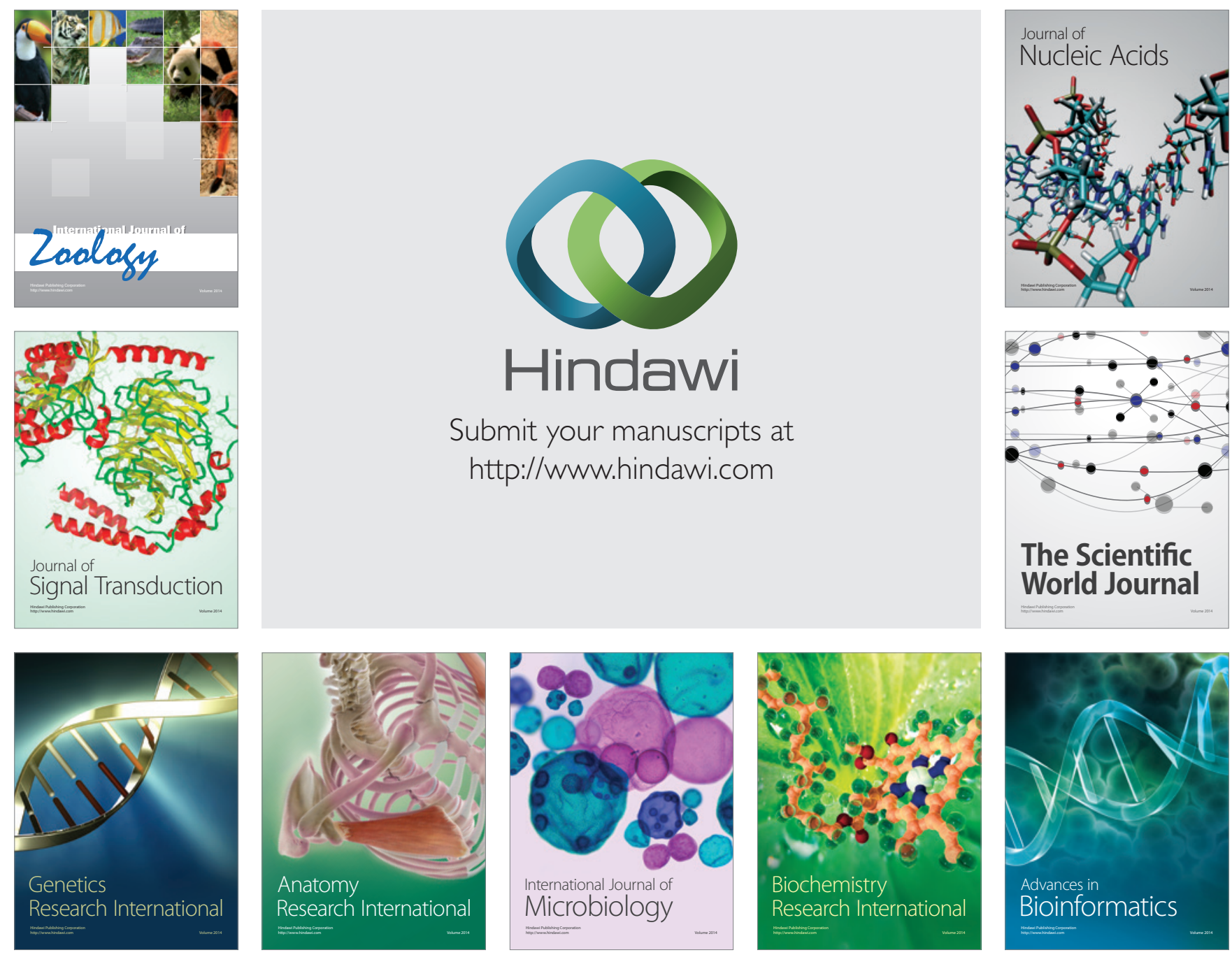

The Scientific World Journal
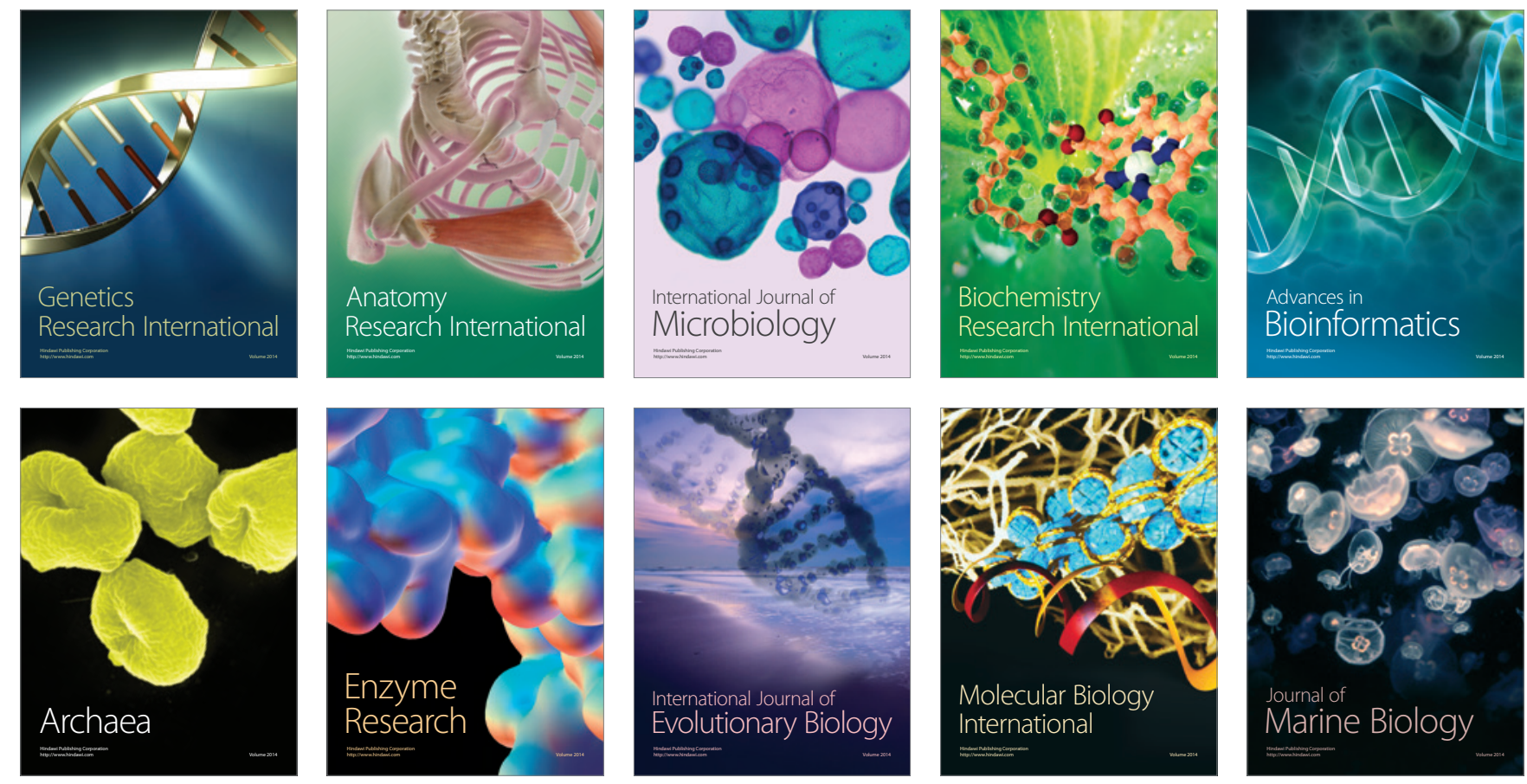